AGRICULTURE AND BIOLOGY JOURNAL OF NORTH AMERICA

ISSN Print: 2151-7517, ISSN Online: 2151-7525, doi:10.5251/abjna.2013.4.3.284.290

(C) 2013, ScienceHuß, http://www.scihub.org/ABJNA

\title{
Effective water management practices in irrigated rice to ensure food security and mitigate climate change in a tropical climate
}

\author{
M. F. Fonteh ${ }^{1}$, F. O. Tabi ${ }^{2}$, A. M. Wariba ${ }^{1}$, and J. $\mathrm{Zie}^{3}$ \\ ${ }^{1}$ Department of Agricultural Engineering, Faculty of Agriculture, University of Dschang, PO \\ Box 447, Dschang, West Region, Cameroon. Tel: +237 7774 0863, Fax: + 2373345 1385, \\ Email: matfonteh@yahoo.com (Corresponding Author) \\ 2 Department of Soil Science, Faculty of Agriculture, University of Dschang, PO Box 222, \\ Dschang, Cameroon. Email: obenft@yahoo.com \\ ${ }^{3}$ Upper Nun Valley Development Authority, PO Box 25, Ndop, NW Region, Cameroon. \\ Email: josephzie@yahoo.co.uk
}

\begin{abstract}
Rice is consumed by billions of people in the world and it is estimated that over 75 percent of the world's rice is produced using continuous flooding water management practices. Studies indicate that continuous flooding has numerous disadvantages like low water use efficiencies and high emissions of methane. In order to ensure food security faced with the increasing competition for water and also to mitigate climate change, it is desirable to propose alternate water management practices to farmers. A study was carried out in Cameroon to compare the performance of local varieties of rice under different water management practices. The objectives were to: evaluate the effect of different water management practices on the growth and yield of three local rice varieties; and to determine the effect of various water management practices on the water use efficiency and water productivity of irrigated rice. Four water management regimes (continuous flooding maintained at a depth of $3 \mathrm{~cm}$, intermittent flow at depths of, 3, 5 and $7 \mathrm{~cm}$ ) and three local rice varieties were tested in a split-plot design with three replicates. The main plot factor was water management regime and the sub-plot factor, variety. The study indicates that the various water management practice do not significantly affect plant height $(p>0.05)$. The varieties were significantly different in plant height $(p<0.05)$. There was a significant $(p<0.05)$ interaction between water management regime and variety on plant height. Between 39 and $47 \%$ of the irrigation water used under continuous flooding as is practiced by most farmers in sub-Saharan Africa can be saved by the adoption of intermittent irrigation at 3-5 $\mathrm{cm}$ depth. The water use efficiency in intermittent irrigation with an application of $3 \mathrm{~cm}$ is about $100 \%$ greater than that in continuous flooding irrigation with the same depth. For intermittent irrigation with a depth of $5 \mathrm{~cm}$, the improvement is about $80 \%$. Intermittent irrigation produces yields which are not significantly different from continuous flooding irrigation but with a water use efficiency of up to $100 \%$ higher. Intermittent water application with a depth of $3 \mathrm{~cm}$ had a water productivity of about $88 \%$ higher than that obtained with continuous flooding irrigation. Intermittent irrigation with applied depths of $3-5 \mathrm{~cm}$ should therefore be promoted in sub-Saharan Africa to ensure food security while at the same time mitigating climate change through reduced production of methane.
\end{abstract}

Keywords: water management, paddy rice, food security, intermittent irrigation, water productivity, climate change mitigation

\section{INTRODUCTION}

Since the available fresh water resources in the world are constant and the population is continually increasing, the available water per capita will continue to decrease resulting in water scarcity or stress in some areas. The competition for water is therefore expected to increase from urban and industrial sectors. Agriculture which consumes the lion share of fresh water withdrawn will be expected to give up more and more water. In addition, climate change is expected to compound the problem of water availability and hence it's very important to 
improve the productivity of water use in agriculture if food security is to be ensured.

In many places the unreliability of water resources both in irrigated and rain fed agriculture is one of the major constraints in achieving food and water security. Recent surveys in rice growing areas in the northwest region of Cameroon (Ngobesing, personal communication) revealed that insufficient irrigation water is one of the major constraints to rice production. Rice farming in these areas is characterized by decreasing yields and conflicts arising from water distribution. This may be one of the reasons responsible for low rice yields in the North West region of Cameroon despite government effort to boost annual rice production to 950,000 tons by 2018 (MINADER, 2009).

Rice is consumed by about three billion people and is a staple food for a large number of people on earth (Wassmann et al., 2009). The number of consumers is expected to increase in future because of increasing population, rapid urbanization and change in diets. Water is one of the most important requirements of paddy rice production. Paddy rice is usually grown in lowland areas under continuous flooded conditions. It is estimated that over 75 percent of the world's rice is produced using continuous flooding water management practices (Van der Hoek et al., 2001). According to Sharma, (1989) the continuous flooding method is very inefficient as about 50-80 percent of the total water input is wasted. Other disadvantages of continuous flooding are: high emissions of methane (Wassmann et al., 2009, FAO, 2010); greater vulnerability to water shortages than other cropping systems (Wassmann, 2010); leaching of soluble nutrients, blocking of soil microbial activities, and reduced mineralization and nutrient release from the soil complexes (Uphoff and Randriamiharisoa, 2002).

Water saving is the main issue in maintaining the sustainability of rice production when water resources are becoming scarce (Arif et al., 2012). In Asia, with relatively more suitable growing conditions for rice, production has declined due to increasing water stress (Aggarwal et al., 2000; Tao et al., 2004). There are a number of alternatives to continuous flooding of rice. One approach which can be used is intermittent irrigation or alternate wetting and drying (AWD). The performance of this approach was evaluated and compared to the continuous flooding method. In the AWD method, irrigation water is applied in certain intervals leading to episodes of non-flooded soil conditions in the fields. The intervals of non-flooded periods can vary from 1 day to more than 10 days depending on the specific management regime and soil/climate conditions. Hence the benefits of AWD can be summarized as: increased water use efficiency (WUE), increased productivity, reduced vulnerability to drought, decreased methane emission and increased food security.

Despite the benefits of the AWD method, most rice farmers in sub-Saharan Africa are still practicing continuous flooding. It is therefore imperative to evaluate the AWD method using local and improved varieties, taking weed management and possible nitrogen losses into consideration. The cultivation of rice in flooded fields requires about $2500-3000 \mathrm{~m}^{3}$ water to produce one ton of rice grain (Bouman et al., 2002). Because most farmers practice continuous flooding, savings of water due to change in the current practice will translate into a significant reduction in the consumption of fresh water for rice farming. For the AWD method to be accepted, farmers would need to be convinced that the yields of their preferred rice varieties under this alternative approach would be similar to yields obtained with continuous flooding. The dissemination and adoption of more efficient water management techniques will entail benefits for the resilience of rice production systems to future droughts.

The objectives of this study were to: evaluate the effect of different water management practices on the growth and yield of three rice varieties; and to determine the effect of various water management practices on the water use efficiency and water productivity of irrigated rice.

\section{METHODOLOGY}

Description of experimental site: The study was carried out in the Ndop plain in Cameroon (Figure 1) situated between latitude $5^{\circ} 4^{\prime} \mathrm{N}$ and $5^{\circ} 10^{\prime} \mathrm{N}$; and longitude $10^{\circ} 15^{\prime} \mathrm{E}$ and $10^{\circ} 50^{\prime} \mathrm{E}$ on an altitude of 1150 $\mathrm{m}$ above sea level (m.a.s.l.). Rice is grown in the plain mainly on hydromorphic soils using continuous flooding methods as is the case in most of subSaharan Africa. Rainfall is the sub equatorial monsoon type with an annual average of between $1200 \mathrm{~mm}$ and $2000 \mathrm{~mm}$. The rainy season begins from mid March and ends by mid November. The mean annual temperature is $21.3^{\circ} \mathrm{C}$. Ndenecho (2009) observed that there is significant water shortage for irrigation of rice in the Ndop Plain during the period from December to February. 


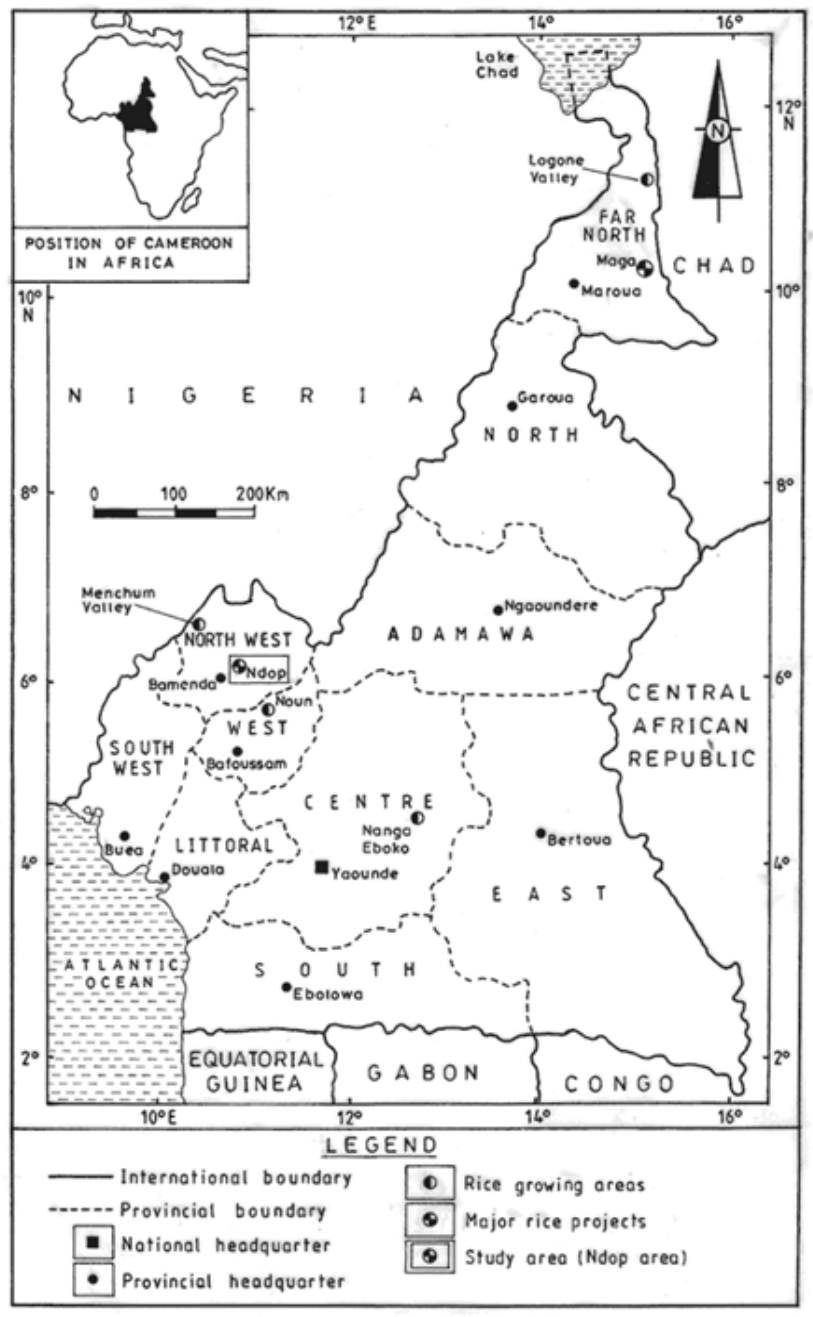

Source: Fonjong and Mbah (2007)

\section{Fig 1: : Location of the study and rice producing areas of Cameroon}

Land preparation and experimental layout: The experimental plot was ploughed, harrowed and puddle to a depth of $15-20 \mathrm{~cm}$ by a rotovator powered by a 4-wheel drive Massey Ferguson 360 tractor. Earth dykes $20-30 \mathrm{~cm}$ wide and $20-25 \mathrm{~cm}$ high were constructed on experimental units (plots) using spades and hoes. The effects of four water management regimes were tested on the growth, yield, water use efficiency and water productivity of three favorite local rice varieties (Tainan 5, TOX and Variety 14) in a split-plot design with 3 replicates. The main plot factor was the water management regime and the sub-plot factor was the variety.
The four water management regimes were: continuous flooding maintained at a depth of $3 \mathrm{~cm}$ $\left(d_{0}\right)$, intermittent flow with application depths of $3 \mathrm{~cm}$ $\left(d_{1}\right), 5 \mathrm{~cm}\left(d_{2}\right)$ and $7 \mathrm{~cm}\left(d_{3}\right)$. The maximum water depth of $7 \mathrm{~cm}$ was chosen with a view to reducing the depth commonly used by local farmers $(15 \mathrm{~cm})$ by half. Each water management regime was randomly assigned to the main plots. Cutthroat flumes and rectangular orifices were used to measure the inflow and outflow of water respectively in the continuous flooding plots, while siphons were used to apply water in intermittent plots. The frequency of intermittent irrigation was three times a week.

Three rice seedlings (32 days old) were planted per hole at a depth of $3 \mathrm{~cm}$. Rice planting was done in straight rows at $20 \times 15 \mathrm{~cm}$ spacing with the aid of calibrated sticks and ropes. Two weedings were done before harvest; the first one 3 weeks after transplanting using a systemic herbicide (HERBEXTRA) and the second one was manual, 11 weeks after transplanting. Fertilizer application was in two splits: the first one, $150 \mathrm{~kg} \mathrm{NPK} /$ ha was applied 5 weeks after transplanting and the second, $150 \mathrm{~kg}$ Urea/ha was applied 10 weeks after transplanting. Deltamethrine and Decis were used to control insect pests.

Growth, yield and water use of rice: Data was collected on the plant height, number of tillers, grain yield and water use of the various treatments. Plant height was measured every 14 days using a meter rule. Five healthy plants were randomly selected from each treatment on which measurements were made. The average value was considered to be the plant height for each experimental unit. The average number of tillers counted on 10 plants in a diagonal within a plot served as the number of tillers per plot. Rice grain yield was determined at harvest, when 80 $\%$ of the panicles had turned golden yellow. The yields were determined from plots of $1 \mathrm{~m}^{2}$ and converted to yields per hectare. The moisture content of the grains was determined in the laboratory and grain yield was corrected to $10 \%$.

For continuous flooding irrigation, the water use was determined as the difference between the cumulative inflow volume and the cumulative outflow volume from planting till harvest. For intermittent irrigation, there was no outflow from the basins, and hence the water use was the cumulative inflow volume into each basin.

Water productivity and water use efficiency: Water productivity $\left(\mathrm{kg} / \mathrm{m}^{3}\right)$ was calculated as the ratio 
of the rice grain yield to the water use for each treatment. The water use efficiency (WUE, \%) was estimated using the equation:

$W U E=\frac{E T P+S \& P}{I R+R N} \times 100$

Where: ETP is the evapotranspiration in $\mathrm{mm}$; $\mathrm{S} \& \mathrm{P}$ is the seepage and percolation in $\mathrm{mm}$; IR is the depth of applied irrigation water in $\mathrm{mm}$; and $\mathrm{RN}$ is the depth of rainfall in $\mathrm{mm}$. In rice fields, evapotranspiration can be obtained from pan evaporation. Daily pan evaporation was measured from a US CLASS A evaporation pan and used to determine ETP given by:

\section{$E T P=$ Kp.Epan}

Where $\mathrm{Kp}$ is pan coefficient and Epan is the pan evaporation in $\mathrm{mm}$. Daily air temperature was measured using a mercury thermometer. The temperature readings were used in determining the appropriate pan coefficient, which is temperature dependent. $\mathrm{RN}$ was measured daily using a rain gauge installed at the experimental site, at $1.7 \mathrm{~m}$ above the ground. Cutthroat flumes were installed at appropriate points in the field to measure inflow (IR) in the continuous flooding water management regime. In intermittent flow treatments, siphons were used to determine the flow into each treatment.

Seepage and percolation (S\&P) of irrigation water was estimated using the water balance equation (Fonteh and Assoumou, 1996), as the residual after accounting for all other variables (change in storage, $\Delta S$; irrigation (IR); rainfall (RN); drainage (DR); and evapotranspiration (ETP)). The change in storage was determined from:

$\Delta S=$ Inflow - Outflow

Where,

Inflow $=I R+R N$

Outflow $=E T P+D R+S \& P$

$S \& P=(I R+R N)-(E T P+D R+\Delta S)$

S\&P was estimated using data collected over a 15day period. The change in storage was measured as the difference in water levels in the basin between two time intervals. Rectangular orifices were installed at appropriate points in the field to measure the outflow (DR) in the continuous flooding water management regime.

Statistical analysis: Because data on growth characteristics were collected over time, time was considered in the analysis as a factor. Therefore, analysis of variance of growth characteristics was performed as a split-split plot design, with time as main plot factor, water management regime as subplot factor and variety as sub-sub plot factor. Intermittent water regimes were compared for S\&P and WUE using a randomized complete block design, with water regime and time of measurement as factors. Where differences in treatment means were significant, means were separated using the Least Significant Difference Test (LSD). The GENSTAT software was used for statistical analysis.

\section{RESULTS AND DISCUSSION}

Plant height: Table 1 shows the height of rice plants under different water management treatments. Plant height varied from 53.04 to $68.82 \mathrm{~cm}$ but the water management regime did not significantly affect plant height $(p>0.05)$. The varieties were significantly different in plant height $(p<0.05)$. There was a significant $(p<0.05)$ interaction between water management regime and variety on plant height. Plant height was highest for Tainan 5 at d0, for TOX at d2 and for variety 14 at d3. Growth of TOX under management $\mathrm{d} 1$ was similar to Tainan 5 under water management $\mathrm{d} 0$. Although there might be varietal differences in growth, the lower depth of irrigation water for rice causes higher day-time temperature and lower night-time temperature, which causes better growth (Mostafazadeh-Fard et al., 2010). With Tainan 5, intermittent irrigation at lower water depths reduced rice growth relative to continuous flooding. This may be attributed to low tolerance to weed infestation. Because of irregular leveling of the paddies, low water levels may not completely cover the soil to smoother weeds. Juraimi et al., (2009) reported that reduced depth of ponding enhances weed emergence and significantly reduces the height of the rice plant. 
Table 1: Effect of water management regime and rice variety on plant height in $\mathrm{cm}$

\begin{tabular}{|l|c|c|c|}
\hline & \multicolumn{3}{|c|}{ Rice varieties } \\
\hline Water management regime & Tainan 5 & TOX & Variety 14 \\
\hline d0 & $56.16 \mathrm{def}$ & $57.02 \mathrm{de}$ & $66.73 \mathrm{ab}$ \\
\hline $\mathrm{d} 1$ & $54.3 \mathrm{gh}$ & $56.56 \mathrm{def}$ & $65.05 \mathrm{~b}$ \\
\hline $\mathrm{d} 2$ & $54.39 \mathrm{fgh}$ & $58.24 \mathrm{~d}$ & $62.47 \mathrm{c}$ \\
\hline d3 & $53.04 \mathrm{~h}$ & $55.56 \mathrm{efg}$ & $68.82 \mathrm{a}$ \\
\hline
\end{tabular}

$\mathrm{d}_{0}=$ continuous flooding maintained at $3 \mathrm{~cm}$ depth, $\mathrm{d}_{1}=$ intermittent $3 \mathrm{~cm}$ water depth, $\quad \mathrm{d}_{2}=$ intermittent $5 \mathrm{~cm}$ water depth and $d_{3}=$ intermittent $7 \mathrm{~cm}$ water depth; means in rows and columns followed by the same letter are not significantly different at $5 \%$ probability

Number of tillers: The tillering pattern in all three varieties was similar (Fig. 2). Tillering was slow in the first 4 weeks after transplanting and increased rapidly between week 4 and week 8 after transplanting. The maximum number of tillers produced was between 13 and 15 . The varieties were not significantly different ( $p>0.05)$ in tillering ability but water management regime significantly $(p<0.05)$ affected number of tillers $(\mathrm{d} 0=8.44, \mathrm{~d} 1=7.95, \mathrm{~d} 2=8.51, \mathrm{~d} 3=8.17)$. The interaction between variety and water management regime on the number of tillers was significant $(p<0.05)$. The highest number of tillers (Table 2) was produced for Tainan 5 with water management $\mathrm{d} 3$, for TOX this was $\mathrm{d} 1$ and for variety 14 it was $\mathrm{d} 3$.

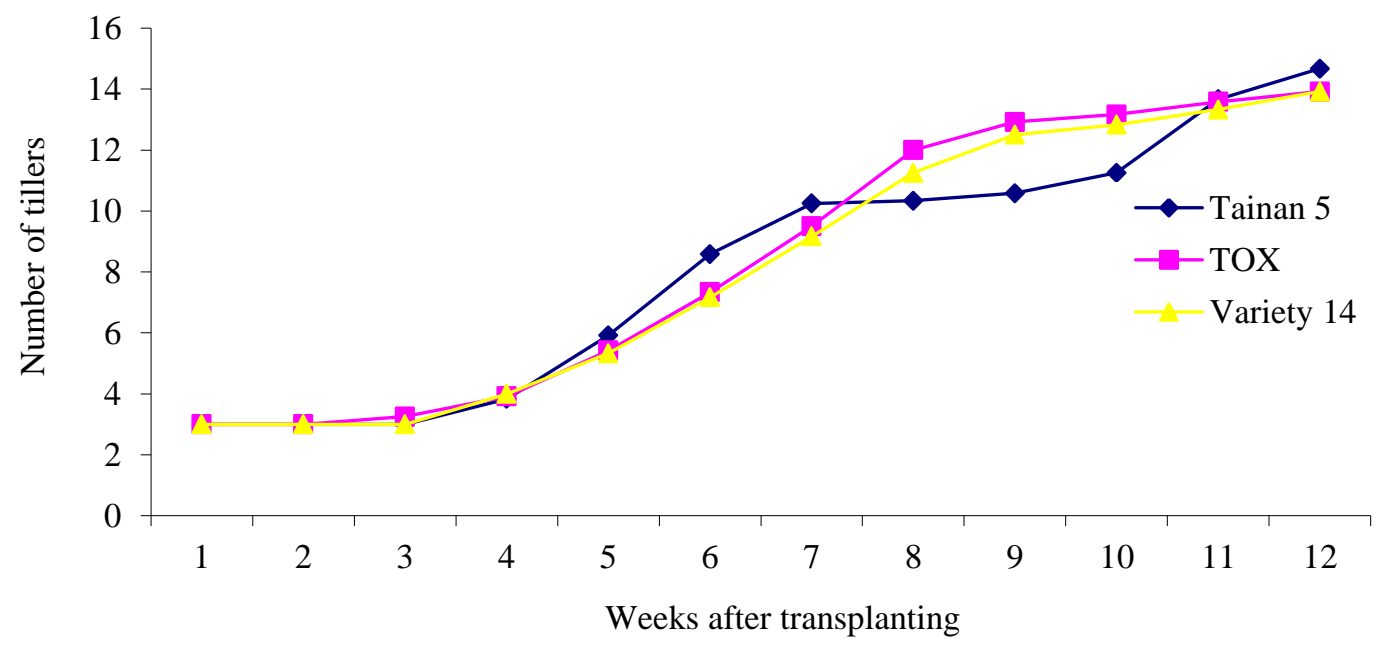

Fig 2: Changes in number of tillers of the different rice varieties during the growth period considered

Table 2: Effect of water management regime and rice variety on number of tillers produced

\begin{tabular}{|l|c|c|c|}
\hline & \multicolumn{3}{|c|}{ Rice varieties } \\
\hline Water management regime & Tainan 5 & TOX & Variety 14 \\
\hline$d_{0}$ & $7.92 \mathrm{~d}$ & $8.81 \mathrm{ab}$ & $7.78 \mathrm{~d}$ \\
\hline $\mathrm{d}_{1}$ & $8.25 \mathrm{~cd}$ & $8.86 \mathrm{a}$ & $8.19 \mathrm{~cd}$ \\
\hline $\mathrm{d}_{2}$ & $7.83 \mathrm{~d}$ & $7.75 \mathrm{~d}$ & $8.28 \mathrm{bcd}$ \\
\hline $\mathrm{d}_{3}$ & $8.69 \mathrm{abc}$ & $8.25 \mathrm{~cd}$ & $8.58 \mathrm{abc}$ \\
\hline
\end{tabular}

$\mathrm{d}_{0}=$ continuous flooding maintained at $3 \mathrm{~cm}$ depth, $\mathrm{d}_{1}=$ intermittent $3 \mathrm{~cm}$ water depth, $\mathrm{d}_{2}=$ intermittent $5 \mathrm{~cm}$ water depth and $d_{3}=$ intermittent $7 \mathrm{~cm}$ water depth; means in rows and columns followed by the same letter are not significantly different at $5 \%$ probability 
Water productivity and water use efficiency: The water use, yield, water productivity and water use efficiency associated with the different water management regimes are presented in Table 3 . Compared to the continuous flooding regime $(\mathrm{d} 0)$, the d1 water management regime reduced water use by $47 \%$, while for d2 water use was reduced by $39 \%$ and $\mathrm{d} 3$ by $20 \%$. This result is in line with the results obtained by Mostafazadeh-Fard et al., (2010) who reported that decreasing the depth of ponded water on the soil surface in irrigated rice reduced the water use by about $23 \%$. The use of modern irrigation techniques can also lead to water savings of more than 50 \% (Saleth and Dinar, 2008; Bouman et al., 2005). Although the water use differed with water regime, their effects on rice grain yield were not significant. The results indicate that between 20 and $47 \%$ of irrigation water used for rice production under continuous flooding can be saved under intermittent irrigation of 3-7 cm depths without any significant reduction in rice grain yield. Results on effects of water management on rice yield vary with agro-ecological zones and year of cropping. Generally, most water-saving methods to date show little decline in yield or at most small gains in output (Uphoff and Randriamiharisoa, 2002). By applying appropriate irrigation management in rice cultivation, a large volume of water can be saved which would help to bring more land under cultivation using the same available amount of water. This will not only enhance food security but water security as well.

Table 3: Effect of water management regime on water use, rice grain yield, water productivity and water use efficiency (WUE)

\begin{tabular}{|l|c|c|c|c|}
\hline Water management regime & Water use $(\mathrm{mm})$ & Yield $(\mathrm{kg} / \mathrm{ha})$ & Water productivity $\left(\mathrm{kg} / \mathrm{m}^{3}\right)$ & WUE (\%) \\
\hline d0 & 2196 & 6265 & 0.285 & 32.3 \\
\hline $\mathrm{d} 1$ & 1168 & 6276 & 0.537 & 65.0 \\
\hline $\mathrm{d} 2$ & 1348 & 5703 & 0.423 & 58.1 \\
\hline $\mathrm{d} 3$ & 1766 & 6490 & 0.367 & 35.0 \\
\hline $\mathrm{LSD}_{0.05}$ & & $\mathrm{~ns}$ & 0.099 & 9.8 \\
\hline
\end{tabular}

$\mathrm{d}_{0}=$ continuous flooding maintained at $3 \mathrm{~cm}$ depth, $\mathrm{d}_{1}=$ intermittent $3 \mathrm{~cm}$ water depth, $\quad \mathrm{d}_{2}=$ intermittent $5 \mathrm{~cm}$ water depth and $d_{3}=$ intermittent $7 \mathrm{~cm}$ water depth; means in rows and columns followed by the same letter are not significantly different at $5 \%$ probability

Water productivity was lowest $\left(0.285 \mathrm{~kg} / \mathrm{m}^{3}\right)$ with continuous flooding (d0) and highest $\left(0.537 \mathrm{~kg} / \mathrm{m}^{3}\right)$ with intermittent irrigation at $3 \mathrm{~cm}$ depth (d1). The differences in water productivity as influenced by water management regime were statistically significant $(p<0.05)$. Water productivity under $d 0$ was low and was similar to that reported for conventional basin flooding (Kahlown et al., 2007). Water productivity under intermittent irrigation $(\mathrm{d} 1, \mathrm{~d} 2, \mathrm{~d} 3$ ) was comparable with that reported with sprinkler irrigation (0.38-0.67 kg/m ${ }^{3}$ ) (Kahlown et al., 2007). Intermittent water application with a depth of $3 \mathrm{~cm}$ therefore had a water productivity of about $88 \%$ higher than that obtained with continuous flooding irrigation.

The average seepage and percolation calculated for different water management regimes and used to determine the WUE increased with depth of ponded water. This result is consistent with the results obtained by Guera et al., (1998). Results from this study indicate that the WUE on farmers' fields with continuous flooding is about $32 \%$. With intermittent irrigation, the WUE increases to about $65 \%$ with d1

and $58.1 \%$ with d2. Intermittent irrigation therefore produces yields which are not significantly different from continuous flooding irrigation but with a WUE of up to $100 \%$ higher. Intermittent irrigation therefore can ensure food security while at the same time mitigating climate change with reduced emissions of methane in intermittent irrigation.

\section{CONCLUSIONS}

Between 20 and $47 \%$ of irrigation water used under continuous flooding as is practiced by most farmers in sub-Saharan Africa can be saved by the adoption of intermittent irrigation at 3-5 cm depth. Intermittent irrigation at these water depths has no negative effect on rice grain yield compared to continuous flooding. Intermittent water application with a depth of $3 \mathrm{~cm}$ resulted in a water productivity of about $88 \%$ higher than that obtained with continuous flooding irrigation. The water use efficiency in intermittent irrigation at 3 $\mathrm{cm}$ depth is about $100 \%$ greater than that in continuous flooding irrigation at the same depth. For intermittent irrigation at $5 \mathrm{~cm}$ depth the improvement is about $80 \%$. To ensure food security and mitigate climate change in rice producing areas, intermittent 
irrigation with a depth of $3-5 \mathrm{~cm}$ should be promoted to replace continuous flooding irrigation.

\section{REFERENCES}

Aggarwal, P.K., Bandyopadhyay, S.K., Pathak, H., Kalra, N., Chander, S and Kumar, S (2000). Analysis of yield trends of the rice-wheat system in north-western India. Outlook Agr., 29:259-268.

Arif, C., Setiawan, B.I., Mizoguchi, M and Doi, R (2012). Estimation of water balance components in paddy fields under non-flooded irrigation regimes by using excel solver. Journal of Agronomy 11(2):53-59.

Bouman, B.A.M., Hengsdijk, H., Hardy, B., Bindraban, P.S., Tuong, T.P., Ladha, J.K. (Eds.) (2002). Water-wise rice production. Proceedings of the international workshop on water-wise rice production, 8-11 April 2002, Los Baños, Philippines. Los Baños -Philippines: International Rice Research Institute, 356 pp.

Bouman, B.A.M., Peng, S., Castañeda, A.R and Visperas, R.M (2005). Yield and water use of tropical aerobic rice systems in the Philippines. Agricultural Water Management 72(2): 87-105.

FAO (2010). Climate-smart agriculture: policies, practices and financing for food security, adaptation and mitigation. Rome: FAO, $42 \mathrm{pp}$.

Fonjong, L.N and Mbah, F.A (2007). The fortunes and misfortunes of women rice producers in Ndop, Cameroon and the implications for gender roles. Journal of International Women's Studies Vol. 8 (4):133-147.

Fonteh, M. F and Assoumou, E (1996). Irrigation and drainage. Course $\mathrm{N}^{0} 011 \mathrm{GR}$, Distance Education Programme. University of Dschang. DschangCameroon: Centre for Distance Education, 192 pp.

Guerra, L.C., Bhuiyan, S.I., Tuong, T.P and Barker, R (1998). Producing more rice with less water from irrigated systems. International Rice Research Institute, Los Baños, 1-22.

Juraimi, A S, Saiful M, Begum, M., Anuar, A.R and Azmi, M (2009). Influence of flooding intensity and duration on rice growth and yield. Pertanika J. Trop. Agric. Sci. 32(2):195-208.

Kahlown, M.A., Raoof A., Zubair, $M$ and Kemper, W.D (2007). Water use efficiency and economic feasibility of growing rice and wheat with sprinkler irrigation in the Indus Basin of Pakistan. Agricultural Water management 87:292-298.

MINADER (Ministry of Agriculture and Rural Development), (2009). Stratégie nationale de développement de la riziculture au Cameroun: mouture III. YaoundéCameroun: MINADER, $21 \mathrm{pp}$.
Mostafazadeh-Fard, B. Jafari F., Mousavi, S and Yazdani, $M$ (2010). Effects of irrigation water management on yield and water use efficiency of rice in cracked paddy soils. Australian Journal of Crop Science 4(3):136-141.

Ndenecho, E.N (2009). Cropping systems and postcultivation vegetation successions: Agro-ecosystems in Ndop, Cameroon. J. Hum Ecol 27(1):27-33.

Saleth, R. M and Dinar, A (2008). Quantifying institutional impacts and development synergies in water resource programs: a methodology with application to the Kala Oya Basin, Sri Lanka, Policy Research Working Paper 4498, Sustainable Rural and Urban Development Team. Washington DC: The World Bank Development Research Group, 71pp.

Sharma, P. K (1989). Effect of period moisture stress on water-use efficiency in wetland rice. Oryza, 26:252257.

Tao, F., M., Yokozawa, Z., Zhang, Y., Hayashi, H. G and Fu, C (2004). Variability in climatology and agricultural production in China in association with the East Asia summer monsoon and El Niño South Oscillation. Climate Res. 28:23-30.

Uphoff, $\mathrm{N}$ and Randriamiharisoa, R (2002). Reducing water use in irrigated rice production with the Madagascar system of rice intensification (SRI). In: Bouman B. A., Hengsdijk H., Hardy B., Bindraban P. S., Thuong T.P., and Ladha J. K. (Eds.), Water-wise rice production. Proceedings of the international workshop on waterwise rice production, 8-11 April 2002, Los Baños, Philippines. Los Baños-Philippines: International Rice Research Institute, 71-87 pp.

Van der Hoek, W., Sakthivadivel R., Renshaw, M., Silver, J. B., Birley, M. H and Konradsen, F (2001). Alternate wet/dry irrigation in rice cultivation: a practical way to save water and control malaria and Japanese encephalitis. Research report 47, Colombo-Sri Lanka: International Water Management Institute, 30 pp.

Wassmann, R (2010). Advanced technologies of rice production for coping with climate change: 'no regret' options for adaptation and mitigation and their practical uptake. Proceedings of the workshop Advanced Technologies for Adaptation for coping with Climate Change: 'No Regret' Options for Adaptation and Mitigation and their Potential Uptake held on 23-25 June 2010 in Los Banos (Philippines), Los BañosPhilippines: International Rice Research Institute.

Wassman, R., Jagadish, S.V.K., Heuer, S., Ismail, A., Redona, E., Serraj, R., Singh, R. K., Howell, G., Pathak, H and Sumfleth, K (2009). Climate change affecting rice production: the physiological and agronomic basis for possible adaptation strategies. In: Donald L. Sparks, (Eds.), Advances in Agronomy, Vol 101. Burlington: Academic Press, 59-122 pp. 